\title{
Genes That Cause Overproduction of Isoamyl Alcohol by Increased Gene-Dosage Effect in Saccharomyces cerevisiae
}

\author{
Dai Hirata and Tadao Hirol \\ Niigata Prefectural Institute of Brewing, Suidouchou-2, Nigata 951, Japan \\ Received June 19, 1990
}

\begin{abstract}
Isoamyl acetate, one of the major components of flavor in a Japanese brewing product, sake, contributes to the fruity flavor of sake. We cloned Saccharomyces cerevisiae genes that cause overproduction of isoamyl alcohol, the precursor of isoamyl acetate, by increased gene-dosage effect. Three plasmids, pScFIr1, pScFlr2, and pScFlr3, were obtained by selection from the yeast genomic DNA which, on a multicopy plasmid, confer a phenotype resistant to 5,5,5-trifluoro-DL-leucine, an analogue of leucine. The cloned DNA fragments in the three plasmids had different restriction maps. Transformed cells with each of the plasmids produced large amounts of both isoamyl alcohol and isoamyl acetate. The gene cloned in the plasmid pScFIr1 was identified as the LEU4 gene encoding $\alpha$-isopropylmalate synthase.
\end{abstract}

Isoamyl acetate (i-AmOAc), which gives a fruity flavor, is one of the major components of sake flavor. The amount of $\mathrm{i}-\mathrm{AmOAc}$ in sake might be controlled by proper regulation of genes responsible for the $\mathrm{i}-\mathrm{AmOAc}$ synthesis.

Isoamyl acetate is synthesized from isoamyl alcohol ( $\mathrm{i}-\mathrm{AmOH})$ and acetyl-CoA through the catalysis of alcohol acetyltransferase, ${ }^{1-4)}$ and the production of $\mathrm{i}-\mathrm{AmOAc}$ depends on the concentration of $\mathrm{i}-\mathrm{AmOH} .{ }^{5)}$ There are two major pathways for the synthesis of $\alpha$ ketoisocaproate $(\alpha \mathrm{KC})$, a precursor of i$\mathrm{AmOH}$ : the L-leucine pathway that synthesizes $\alpha \mathrm{KC}$ from glucose and the Ehrlich mechanism that synthesize $\alpha \mathrm{KC}$ from L-leucine (Fig. 1). ${ }^{6)}$ The L-leucine synthetic pathway includes $\alpha$ isopropylmalate (IPM) synthase, IPM isomerase, and $\beta$-IPM dehydrogenase. ${ }^{7)}$ The LEU4 gene encodes $\alpha$-IPM synthase, the first enzyme of the L-leucine synthetic pathway. ${ }^{8,9}$ However, strains that bear a disrupted leu4 gene are Leu ${ }^{+}$, with $20 \%$ of the wild-type level of $\alpha$-IPM synthase activity. ${ }^{10)}$ Therefore, it is suggested that isozymes of $\alpha$-IPM synthase might exist. The isozymes are expected to be encoded by $L E U 7$ and $L E U 8 .^{11)}$ In a leu4 genetic background, a mutation in either of the LEU5, LEU7, or LEU8 locus results in the
Leu $^{-}$phenotype. ${ }^{8,11)}$ The LEU5-encoded enzyme has not been identified yet. The LEU5 gene is a $P E T$-like gene that is required for growth on most, but not all, nonfermentable carbon sources (glycerol, lactate, acetate, but not on ethanol) and is not essential for leucine synthesis. ${ }^{12)}$ The second and the third enzymes in the L-leucine synthetic pathway are encoded by the $L E U 1$ and $L E U 2$ genes, respectively. ${ }^{13,14)}$ Enzymatic activity of $\alpha$-IPM synthase, but not the other two enzymes, is inhibited by L-leucine. ${ }^{15}$ ) The amounts of IPM isomerase and $\beta$-IPM dehydrogenase are repressed slightly by L-leucine, and are repressed markedly by the presence of both L-leucine and L-threonine. The repression of the $L E U 1$ and $L E U 2$ genes occurs, at least in part, at the level of transcription. ${ }^{13)}$ The amount of $\alpha$-IPM synthase is also regulated by the general control system. ${ }^{16-19)}$

As mentioned above, in the absence of $\mathrm{L}$ leucine, $\mathrm{i}-\mathrm{AmOH}$ is mainly derived from $\alpha \mathrm{KC}$ through the L-leucine synthetic pathway. On the other hand, in the presence of L-leucine, major route of $\mathrm{i}-\mathrm{AmOH}$ synthesis is the Ehrlich mechanism, because the $\alpha \mathrm{KC}$ synthesis from glucose is negatively controlled by L-leucine. If the negative control of L-leucine was relieved, 
$\alpha \mathrm{KC}$ can be synthesized directly from glucose and the amount of $\mathrm{i}-\mathrm{AmOH}$ produced would be increased, because both of the $\mathrm{i}-\mathrm{AmOH}$ synthesizing routes are operating. These possibilities were supported by an observation that mutants resistant to a leucine analogue, 5,5,5trifluoro-DL-leucine (FL), which have an $\alpha$-IPM synthase resistant to feedback inhibition by L-leucine, produce more i-AmOAc than the parental strain. ${ }^{20)}$

To control the amount of $\mathrm{i}-\mathrm{AmOAc}$ in sake, we attempted to control the expression of genes encoding enzymes of $\mathrm{i}-\mathrm{AmOH}$ pathway. For the first step of this purpose, we cloned genes that cause overproduction of $\mathrm{i}-\mathrm{AmOH}$ by increased gene-dosage effect. When $S$. cerevisiae cells harbored a multicopy plasmid bearing the gene for the FL-target enzyme, a much higher level of the gene products would be produced and the cell may become FL-resistant $\left(\mathrm{FL}^{\mathrm{r}}\right)$. According to this strategy, we transformed yeast cells with a genomic bank constructed with a multicopy vector, pYII, and selected for $\mathrm{FL}^{\mathrm{r}}$ transformants. These transformants produced higher amounts of $\mathrm{i}-\mathrm{AmOH}$

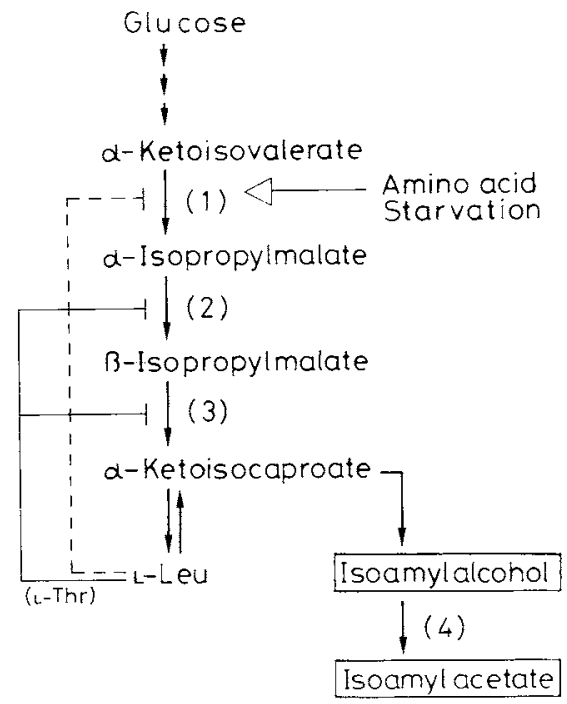

Fig. 1. Biosynthesis of Isoamyl Acetate in Yeast.

(1) $\alpha$-isopropylmalate synthase (LEU4); (2) isopropylma1ate isomerase $(L E U I) ;(3) \beta$-isopropylmalate dehydrogenase (LEU2); (4) alcohol acetyl transferase; $\longrightarrow$, repression; ---, feedback inhibition; $\longrightarrow$, general control. and i-AmOAc.

\section{Materials and Methods}

Strains and plasmids. The $S$. cerevisiae strains used and their relevant genotypes are listed in Table I. A YEp-type shuttle vector $\mathrm{pYI1}^{22)}$ contains $L E U 2$ and $U R A 3$ genes and a $2-\mu \mathrm{m}$ origin of replication. A YCp-type shuttle vector $\mathrm{YCp} 50^{23)}$ contains the $U R A 3$ gene and a yeast centromere CEN4. They also carry the ampicillin- and tetracyclineresistance genes for selection in Escherichia coli.

Media. MM medium contains $0.67 \%$ Yeast Nitrogen Base without amino acids and $2 \%$ glucose. MMFL medium is MM containing $1 \mathrm{mM}$ FL. MM5 medium contains $5 \%$ glucose instead of $2 \%$ glucose. FPM medium contains $1.34 \%$ Yeast Nitrogen Base without amino acids and $10 \%$ glucose. YEPD medium contains $1 \%$ yeast extract, $2 \%$ peptone, and $2 \%$ glucose. If necessary, these media were solidified with $2 \%$ agar or supplemented with amino acids $(50 \mathrm{mg} / \mathrm{l}$ each).

DNA preparation and recombinant plasmid construction. Plasmid DNA was prepared by the alkaline-SDS method of Birnboim and Doly, ${ }^{24)}$ and then purified by cesium chloride-ethidium bromide density gradient centrifugation as described by Davis et $a .^{25}{ }^{25}$ Restriction endonucleases and modifying enzymes were purchased from Toyobo Co. and used under the conditions recommended by the supplier.

Yeast and E. coli transformation. The protoplast transformation method ${ }^{21)}$ was used for $S$. cerevisiae. Transformation of $E$. coli was done by the method of Cohen et al. ${ }^{26)}$

Measurement of the flavor components produced by yeast transformants. Cells were cultured with shaking in $5 \mathrm{ml}$ of MM5 liquid medium at $28^{\circ} \mathrm{C}$ for 2 days, and portions of their cultures were added to $25 \mathrm{ml}$ of fresh FPM liquid medium and left at $28^{\circ} \mathrm{C}$ for 4 days without shaking. The culture supernatant was obtained by centrifugation and its flavor components, i.e., $\mathrm{i}-\mathrm{AmOH}$, i-AmOAc, and isobutyl alcohol (i-BuOH) were detected by head space gas chromatography, ${ }^{27,28)}$

Table I. Saccharomyces cerevisiae STRAins

\begin{tabular}{lll}
\hline Strain & \multicolumn{1}{c}{ Genotype } & \multicolumn{1}{c}{ Source } \\
\hline YIYD & a leu2-3, 112 his4 lys & Yamashita $^{21}$ \\
AH22 & a leu2-3, 112 his4 canl & Yamashita $^{21}$ \\
YIY343 & a ura3 & Yamashita $^{8}$ \\
HB190 & a leu4 leu5 & Kohlhaw $^{87}$ \\
\hline
\end{tabular}


Measurement of FL resistance. Cells were freshly grown on MM plates and replicated onto MM plates containing increasing concentrations of $\mathrm{FL}(1.0,1.5,2.0,2.5$, and $3.0 \mathrm{~mm}$ ). Cell growth was observed after cultivation at $28^{\circ} \mathrm{C}$ for 4 days. The colonies that developed on the MM plates containing variable concentrations of FL were regarded as FL-resistant.

\section{Results}

Cloning of DNA responsible for overproduction of $i-A m O H$

The genomic DNA library ${ }^{29)}$ of S. cerevisiae $\mathrm{AH} 22$ on the multicopy plasmid pYI1 was used to transform $S$. cerevisiae YIYD into leucine prototrophs $\left(\mathrm{Leu}^{+}\right)$. The transformants freshly grown on $\mathrm{MM}$ plates were replicated onto MMFL plates. Transformants that grew on MMFL plates were regarded as $\mathrm{FL}^{\mathrm{r}}$ clones. At a concentration of $1 \mathrm{~mm}, \mathrm{FL}$ completely

Table II. Production of the Flavor COMPONENTS BY THE TRANSFORMANTS

\begin{tabular}{llccc} 
& & \multicolumn{3}{c}{ Flavor components $^{b}$} \\
\cline { 3 - 5 } Strain & (Plasmid) $^{a}$ & $\begin{array}{c}\text { Isoamyl } \\
\text { alcohol } \\
\text { (ppm) }\end{array}$ & $\begin{array}{c}\text { Isoamyl } \\
\text { acetate } \\
\text { (ppm) }\end{array}$ & $\begin{array}{c}\text { Isobutyl } \\
\text { alcohol } \\
\text { (ppm) }\end{array}$ \\
\hline YIYD & (pYI1) & 54 & N.D. ${ }^{c}$ & 39 \\
YIYD & (pScFlrl) & 142 & 1.6 & 36 \\
YIYD & (pScFlr2) & 76 & 0.7 & 88 \\
YIYD & (PScF1r3) & 94 & 0.8 & 78 \\
\hline
\end{tabular}

a Strain YIYD was transformed with the indicated plasmid.

${ }^{b}$ Cells were cultured in FPM liquid medium at $28^{\circ} \mathrm{C}$ for 4 days. Values are the averages from assays of at least five independent cultures.

c Not detectable. inhibited the growth of the recipient YIYD carrying the vector pYIl.

Fifteen $\mathrm{FL}^{\mathrm{r}}$ transformants were obtained from approximately $6 \times 10^{3} \mathrm{Leu}^{+}$transformants. All the fifteen transformants produced more $\mathrm{i}-\mathrm{AmOH}$ than YIYD carrying $\mathrm{pYI1}$. The amounts of flavor components in three typical clones of the fifteen transformants are listed in Table II. Plasmids (designated as pScFlr1, pScFlr2, and pScFlr3) were prepared from the $\mathrm{FL}^{\mathrm{r}}$ transformants and analyzed by restriction (Fig. 2). Sizes of the inserted DNA fragments in the plasmids pScFlr1, 2, or 3 were 5.6, 3.4, or 6.7 kilobases $(\mathrm{kb})$, respectively. These inserts had different restriction maps, indicating that they are different.

Transformants carrying each of the plasmids showed different FL resistances (Table III). The strain YIYD harboring pScFlr1 had the highest resistance.

The concentrations of flavor components in

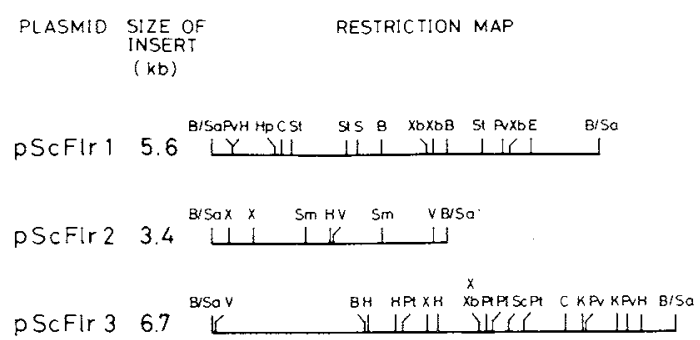

Fig. 2. Restriction Maps of the Inserted DNA Segments.

The original plasmids pScFlrl, pScFlr2, pScFlr3 were restriction analyzed. The restriction sites for $P v u I \mathrm{II}(\mathrm{Pv})$, HindIII (H), HpaI (Hp), ClaI (C), StuI (St), SalI (S), BamHI (B), XbaI (Xb), EcoRI (E), XhoI (X), SmaI (Sm), $E c o R V(\mathrm{~V}), P s t \mathrm{I}(\mathrm{Pt}), P v u \mathrm{I}(\mathrm{PI}), \operatorname{Sacl}(\mathrm{Sc}), \operatorname{KpnI}(\mathrm{K})$, and BamHI-Sau3A boundary $(\mathrm{B} / \mathrm{Sa})$ are indicated.

Table III. 5,5,5-Trifluoro-1)L-LEUCINE Resistance of THE Transformants

\begin{tabular}{|c|c|c|c|c|c|c|}
\hline \multirow{3}{*}{ Strain } & \multirow{3}{*}{ (Plasmid) $^{a}$} & \multicolumn{5}{|c|}{ Growth ${ }^{b}$} \\
\hline & & \multicolumn{5}{|c|}{$\mathrm{FL}(\mathrm{mM})$} \\
\hline & & 1.0 & 1.5 & 2.0 & 2.5 & 3.0 \\
\hline YIYD & (pYII) & - & - & - & - & - \\
\hline YIYD & $(\mathrm{pScF} 1 \mathrm{r} 1)$ & ++ & ++ & $t+$ & + & + \\
\hline YIYD & $(\mathrm{pScF} 1 \mathrm{r} 2)$ & ++ & $t+$ & $t$ & \pm & - \\
\hline YIYD & $(\mathrm{pScF} 1 \mathrm{r} 3)$ & $+t$ & ++ & + & + & \pm \\
\hline
\end{tabular}

a Strain YIYD was transformed with the indicated plasmid.

${ }^{b}++$, very good growth; + good growth; \pm , poor growth; and - , no growth. 
the FPM medium cultivated with the transformants increased to 1.5 to 3 times that produced by strain YIYD carrying pYI1 (Table II). The amount of $\mathrm{i}-\mathrm{AmOAc}$ in the medium produced by the transformants was also high in parallel with the amount of $\mathrm{i}-\mathrm{AmOH}$ produced. The transformant carrying pScFlr1 produced almost the same amount of $\mathrm{i}-\mathrm{BuOH}$ as that of the control, while those carrying $\mathrm{pScF} / \mathrm{l} 2$ or pScFlr3 produced more $\mathrm{i}-\mathrm{BuOH}$ than the control.

Effects of plasmid copy number on the cell phenotype

To find if the phenotype of transformants was due to increased gene-dosage effect, the cloned DNA fragments were inserted into the YCp-type vector YCp50. Plasmid pDH5 was constructed by ligating a $7.2-\mathrm{kb} \quad E c o \mathrm{RV}$ fragment of pScFlr1 containing the cloned 5.6-kb insert with a $6.3-\mathrm{kb} E c o \mathrm{RV}$ fragment of YCp50. Plasmid pDH6 was constructed by ligating a 4.2-kb EcoRI-SalI fragment of pScFlr2 containing the cloned $3.4-\mathrm{kb}$ insert with a 7.3-kb EcoRI-SalI fragment of YCp50. The transformants carrying the $\mathrm{YCp} 50$-based plasmid, pDH5 or pDH6, did not have a FL-resistant phenotype (Table IV), and produced $\mathrm{i}-\mathrm{AmOH}$ at a similar level to that of the host cells (Fig. 3). These results indicate that both the FL $\mathrm{F}^{\mathrm{r}}$ phenotype and overproduction of $\mathrm{i}$-AmOH were caused by increased genedosage effect.

Table IV. EfFEcts of Plasmid TyPE ON THE Growth of Transformants on MMFL Plates

\begin{tabular}{llll} 
Strain & (Plasmid) $^{a}$ & $\begin{array}{c}\text { Plasmid } \\
\text { type }\end{array}$ & $\begin{array}{c}\text { Growth on } \\
\text { MMFL plate } \\
\text { MML }\end{array}$ \\
\hline YIY343 & $($ pYI1) & YEp & - \\
YIY343 & (YCp50) & YCp & - \\
YIY343 & (pScF1r1) & YEp & + \\
YIY343 & (pDH5) & YCp & - \\
YIY343 & (pScF1r2) & YEp & + \\
YIY343 & (pDH6) & YCp & -
\end{tabular}

a Strain YIY343 was transformed with the indicated plasmid.

b $\quad+$, good growth; - , no growth.

\section{Identification of the DNA clone on pScFlrI}

Comparison of the restriction map of the cloned DNA on pScFlr1 with those of the leucine synthetic genes ${ }^{9,12-14)}$ showed that the insert contains a segment with the same restriction map as that of the $L E U 4$ gene, but it is clearly different from those of the $L E U 1$, $L E U 2$, and LEU5 genes (Fig. 4). To confirm that the cloned DNA on pScFlr1 contains

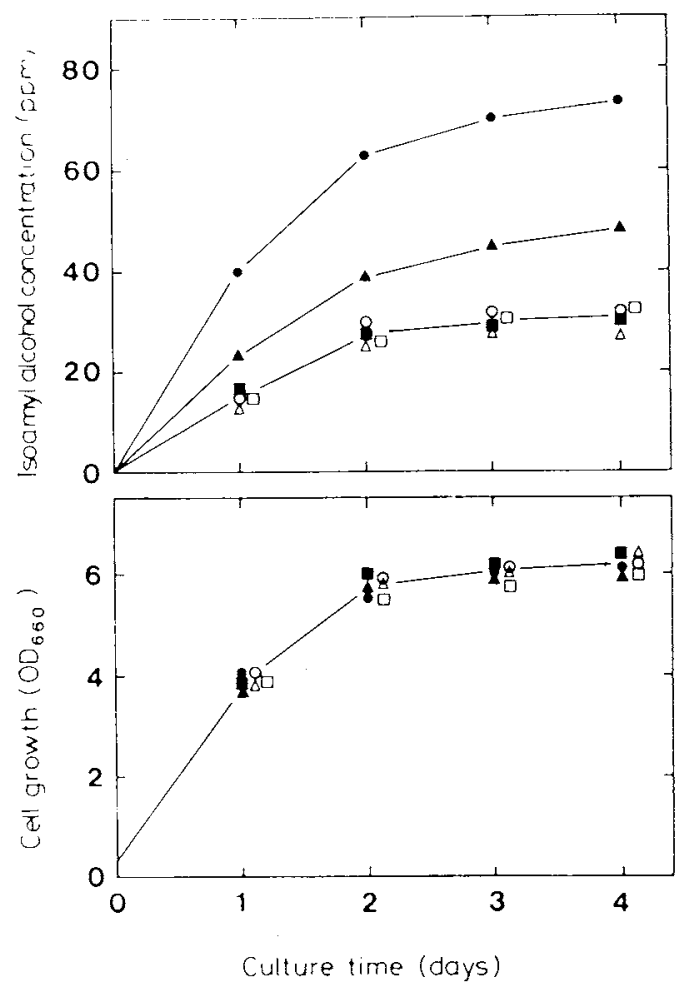

Fig. 3. Effects of Plasmid Type on the Production of $\mathrm{i}-\mathrm{AmOH}$.

Strain YIY343 was transformed with the following plasmids: - YIY343 carrying pScFIr1; O, YIY343 carrying pDH5; $\boldsymbol{\Delta}$, YIY343 carrying pScFIr2; $\triangle$, YIY343 carrying pDH6; $\mathbf{\square}$, YIY343 carrying pYI1; $\square$, YIY343 carrying YCp50.

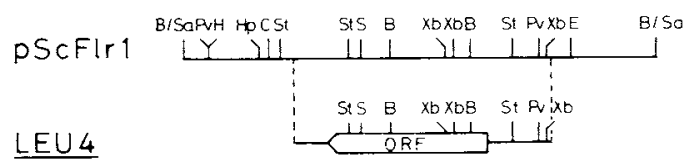

Fig. 4. Comparison of the Restriction Map between the Insert of pScFlrl and LEU4 Gene.

Abbreviations for restriction sites are as in Fig. 2. ORF, open reading frame. 
LEU4, strain HB190 (leu4 leu5) was transformed with pScFlr1 and pDH5 for the leucine prototroph. The $\mathrm{Leu}^{+}$transformants with each of the plasmids grew normally on MM medium, but not on a nonfermentable carbon source (glycerol), showing the phenotype expected for $L E U 4$ leu 5 transformants because leu 5 strains are $\mathrm{Pet}^{-}$and leu4 strains are $\mathrm{Pet}^{+}$. Furthermore, after cultivation of the transformants on non-selective medium (YEPD), Leu ${ }^{-}$ segregants were frequently obtained. These results indicate that these plasmids complement only leut mutations. Therefore, it is concluded that the cloned DNA on pScFlrl contains LEU4.

\section{Discussion}

This study has shown that overproduction of $\mathrm{i}-\mathrm{AmOH}$ can be achieved by increasing the copy number of the LEU4 gene. i-AmOH productivity of the transformants differed significantly with the type of plasmids used as the vector. Increased $L E U 4$ gene dosage by ligation of the multicopy YEp-type plasmid was most effective for $\mathrm{i}-\mathrm{AmOH}$ production (Table II and Fig. 3). The result suggests that the amount of $\mathrm{i}-\mathrm{AmOH}$ in sake may be controlled by the dosage of the gene.

The cloned gene on pScFlr1 was identified as LEU4. The cloned DNAs in the plasmids pScFlr2 and pScFlr3 have not been identified. The restriction maps of pScFlr2 and pScFlr3 were different from those of $L E U 1,{ }^{13)} L E U 2,{ }^{14}$ ) $L E U 4,{ }^{9\}}$ and $L E U 5^{12)}$ at the five restriction sites examined (BamHI, PvuII, XhoI, HindIII, and $S a l \mathrm{I})$. This suggested that cloned DNAs on pScFlr2 and pScFlr3 were different from the above four genes.

The cloned DNAs on pScFlr1, 2, and 3, when present on a multicopy plasmid, could confer on the transformed cell overproduction of $\mathrm{i}-\mathrm{AmOH}$. The multicopy vector pYI1 used in this study contains the LEU2 gene that encodes $\beta$-IPM dehydrogenase for L-leucine synthetic pathway. The transformants carrying only the vector plasmid did not produce a large amount of $\mathrm{i}-\mathrm{AmOH}$. However, we cannot ignore a possibility that the overproduction of $\mathrm{i}-\mathrm{AmOH}$ may be the result of increased dosage of $L E U 2$ in addition to the cloned DNAs.

The transformants carrying the cloned DNAs on a multicopy plasmid produced 1.5 to 3 times the $\mathrm{i}-\mathrm{AmOH}$ of those produced by the control strains [YIYD (a leu2-3, 112 his4 lys7) and YIY343 (a ura3)] carrying pYI1 (Table II and Fig. 3). Two host strains used in this study, YIYD and YIY343, showed differences in the production of i-AmOH. The YIYD transformants carrying pYI1, pScFlr1, or pScFlr2 produced more $\mathrm{i}-\mathrm{AmOH}$ than the YIY343 transformants carrying the same plasmids (Table II and Fig. 3). We suppose that this difference might be due to the difference of the selection markers used (LEU2 for strain YIYD and $U R A 3$ for strain YIY343) or physiological differences of the host strains.

In the practical application of this method in sake brewing, L-leucine and other amino acid composition of sake-mash would significantly affect the production of $\mathrm{i}-\mathrm{AmOH}$.

Acknowledgments. We thank I. Yamashita and R. Akada for helpful discussions and advice, and for providing strains. We also thank G. B. Kohlhaw for providing strains, and S. Fukui, T. Miyakawa, and E. Tsuchiya for advice.

\section{References}

1) K. Nordström, J. Inst. Brew., 69, 142 (1963).

2) D. Howard and R. G. Anderson, J. Inst. Brew., 82, 70 (1976).

3) T. Ishikawa and K. Yoshizawa, Agric. Biol. Chem., 43, 45 (1979).

4) K. Yoshioka and N. Hashimoto, Agric. Biol. Chem., 45, 2183 (1981).

5) K. Kuriyama, S. Ashida, Y. Saito, K. Suginami and S. Imayasu, Hakkoukogaku, 64, 169 (1986).

6) C. Rainbow, "The Yeast," Vol. III, ed. by J. S. Harrison and A. H. Rose, Academic Press Inc., New York, 1970, pp. 190-199.

7) E. W. Jones and G. R. Fink, "Metabolism and Gene Expression," ed. by J. N. Strathern, E. W. Jones and J. R. Broach, Cold Spring Harbor Laboratory, Cold Spring Harbor, New York, 1982, pp. 181-299.

8) L. L. Chang, T. S. Cunningham, P. R. Gatzek, W. Chen and G. B. Kohthaw, Genetics, 108, 91 (1984).

9) J. P. Beltzer, L. L. Chang, A. E. Hinkkanen and G. B. Kohlhaw, J. Biol. Chem., 261, 5160 (1986). 
10) L. L. Chang, P. R. Gatzek and G. B. Kohlhaw, Gene, 33, 333 (1985).

11) P. Drain and P. Schimmel, Genetics, 119, 13 (1988)

12) P. Drain and P. Schimmel, Mol. Gen. Genet, 204, 397 (1986).

13) Y.P. Hsu and P. Schimmel, J. Biol. Chem., 259, 3714 (1984).

14) B. Ratzkin and J. Carbon, Proc. Natl. Acad. Sci. U.S.A., 74, 487 (1977).

15) T. Satayanarayana, H. E. Umbarger and G. Lindegren, J. Bacteriol., 96, 2018 (1968).

16) Y. P. Hsu, G. B. Kohlhaw and P. Niederberger, $J$. Bacteriol., 150, 969 (1982).

17) I. A. Hope and K. Struhl, Cell, 43, 177 (1985).

18) P. P. Mueller and A. G. Hinnebusch, Cell, 45, 201 (1986)

19) L. Guarente, Cell, 52, 303 (1988).

20) S. Ashida, E. Ichikawa, K. Suginami and S. Imayasu, Agric. Biol. Chem., 51, 2061 (1987).
21) I. Yamashita, T. Maemura, T. Hatano and S. Fukui, J. Bacteriol., 161, 574 (1985).

22) I. Yamashita and S. Fukui, Agric. Biol. Chem., 47, 2689 (1983).

23) M. D. Rose, P. Novick, J. H. Thomas, D. Botstein and G. R. Fink, Gene, 60, 237 (1987).

24) H. C. Birnboim and J. Doly, Nucl. Acids Res., 7, 1513 (1979).

25) R. W. Davis, D. Botstein and J. R. Roth, "Advanced Bacterial Genetics,"Cold Spring Harbor Laboratory, Cold Spring Harbor, New York, 1980.

26) S. N. Cohen, A. C. Y. Chang and L. Hsu, Proc. Natl. Acad. Sci. U.S.A., 69, 2110 (1972).

27) K. Yoshizawa, Nippon Jōzōkyōkai Zasshi, 68, 59 (1973).

28) H. Iwata, N. Nakajima, A. Mizuno, T. Izumi, E. Ikeda, T. Kumagai, N. Umeda and T. Tanaka, Nippon Jōzōkyōkai Zasshi, 83, 411 (1988).

29) I. Yamashita, M. Nakamura and S. Fukui, $J$. Bacteriol., 169, 2142 (1987). 